\title{
PERSEPSI PELANGGAN TERHADAP MANFAAT KEGIATAN CREATING SHARED VALUE DAN KEBERLANJUTAN USAHA PT UNILEVER INDONESIA TBK
}

\author{
Henny Henny ${ }^{1}$, Olivia Dorothea Husin ${ }^{2}$ \\ ${ }^{1}$ Jurusan Akuntansi, Universitas Tarumanagara, Jakarta \\ Email: henny@fe.untar.ac.id \\ ${ }^{2}$ Jurusan Akuntansi, Universitas Tarumanagara, Jakarta \\ Email: olivia.125180524@stu.untar.ac.id
}

\begin{abstract}
The company as an entity that does business in producing and selling its products to consumers, cannot be separated from the environment around the company. This is because the company will produce products that will be sold for the desired profitability and affect the surrounding environment, so the company is also required to creating shared value, which have an impact on the problem of business sustainability. The purpose of this study was to obtain empirical evidence of customer perceptions about the benefits of creating shared value activities and business sustainability of PT Unilever Indonesia Tbk on the products purchased. The population to be sampled is a randomly selected Unilever product customer in West Jakarta, who has the same chance of being selected as a sample. The research sample was 30 samples. Customers have responded well to the benefits of creating shared value for their own customers and have a positive impact on the company because it will benefit the sustainability of PT Unilever Indonesia Tbk. The result of the customer's perception of the benefits of creating shared value is a higher percentage of agree that the product is easy to find because it has a good logistics system and competitive advantage over Unilever's product innovations. The samples were taken only from West Jakarta, so the results cannot be generalized to all Unilever product customers in Indonesia. This research is expected to improve the company's reputation for the benefits of creating shared value activities and their impact on the business sustainability of PT Unilever Indonesia Tbk.
\end{abstract}

Keywords: Customer's perception, creating shared value, sustainability business

ABSTRAK
Perusahaan sebagai entitas yang melakukan bisnis dalam memproduksi dan menjual produknya terhadap konsumen, tidak terlepas dari lingkungan sekitar perusahaan berada. Hal ini dikarenakan perusahaan akan memproduksi produk yang akan dijual untuk profitabilitas yang diinginkan dan mempengaruhi lingkungan sekitar, maka perusahaan pun dituntut untuk melakukan creating shared value, yang berdampak pada masalah keberlanjutan usahanya. Tujuan dari penelitian ini adalah untuk memperoleh bukti empiris persepsi pelanggan tentang manfaat kegiatan creating shared value dan keberlanjutan usaha PT Unilever Indonesia Tbk terhadap produk yang dibeli. Populasi yang akan dijadikan sampel adalah pelanggan produk Unilever di Jakarta Barat yang dipilih secara acak, yang memiliki peluang yang sama untuk dipilih menjadi sampel. Sampel penelitian sebanyak 30 sampel. Pelanggan telah merespon dengan baik manfaat kegiatan creating shared value bagi pelanggannya sendiri serta berdampak positif bagi perusahaan karena akan bermanfaat bagi keberlanjutan PT Unilever Indonesia Tbk. Hasil dari persepsi pelanggan terhadap manfaat kegiatan creating shared value lebih tinggi persentase setujunya terletak pada produk yang mudah dicari karena memiliki sistem logistik yang baik dan keunggulan kompetitif atas inovasi produk Unilever. Sampel yang diambil hanya dari Jakarta Barat, sehingga hasilnya tidak bisa dijadikan generalisasi untuk semua pelanggan produk Unilever di Indonesia. Penelitian ini diharapkan dapat meningkatkan reputasi perusahaan atas manfaat kegiatan creating shared value dan dampaknya terhadap keberlanjutan usaha PT Unilever Indonesia Tbk.

Kata Kunci: Persepsi pelanggan, creating shared value, keberlanjutan usaha

\section{PENDAHULUAN \\ Latar Belakang}

Perusahaan sebagai entitas yang melakukan bisnis dalam memproduksi dan menjual produknya terhadap konsumen, tidak terlepas dari lingkungan sekitar perusahaan berada. Hal ini dikarenakan perusahaan akan memproduksi produk yang akan dijual untuk profitabilitas yang 


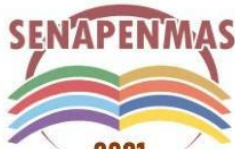

2021

diinginkan. Kegiatan perusahaan yang memproduksi dan menjual produk tersebut berdampak pada lingkungan sekitar, maka perusahaan pun dituntut untuk melakukan creating shared value, yang berdampak pada masalah keberlanjutan usahanya. Masalah keberlanjutan usaha perusahaan perlu dipikirkan dengan seksama untuk menjaga hubungan dengan para stakeholder. Untuk mengatasi masalah ini, maka perusahaan perlu membuat laporan keberlanjutan (sustainability reporting).

Beberapa laporan yang merujuk pada laporan keberlanjutan (Gunawan, 2015), misalnya laporan pembangunan berkelanjutan (sustainable development report), laporan lingkungan, sosial dan tata kelola (environmental, social and governance/ESG report), creating shared value (CSV) report, atau bahkan laporan tanggung jawab sosial perusahaan (CSR report). Semua laporan tersebut pada dasarnya sama, yaitu merujuk pada laporan keberlanjutan, hanya saja terminologi dan penekanan informasi yang berbeda.

Creating Shared Value yang memberikan informasi mengenai manfaat dari kegiatan Corporate Social Responsibility. Creating Shared Value menurut Porter dan Kramer (2011) memiliki dua aspek penting atas shared value strategies dimana semua ini dilakukan melalui kebijakan dan prakteknya operasional perusahaan. Aspek pertama, mereka harus menciptakan nilai untuk perusahaan melalui persaingan kompetitif, aspek penting yang siap dikembangkan dalam publikasi atas strategi dan keberlanjutan. Aspek kedua, mereka harus menciptakan nilai untuk sosial melalui kondisi sosial di masa depan dalam komunitas dimana operasional perusahaan merupakan hal yang diteliti atas kinerja sosial perusahaan.

Menurut Porter dan Kramer (2011) bahwa ada tiga kerangka untuk menciptakan shared value, yaitu reconceiving products and markets, redefining productivity in the value chain, and building supportive industry clusters di lokasi perusahaan berada. Hasil penelitian Spitzeck dan Chapman (2012) menyajikan bahwa dengan strategi diferensiasi akan mengurangi dampak negatif dimana meningkatkan keuangan, sosial dan kinerja lingkungan pada klien BASF di Brazil.

Salah satu kerangka dalam creating shared value (CSV) (Porter dan Kramer, 2011) yaitu reconceiving products and markets, dimana kebutuhan masyarakat yang besar pada kesehatan, perumahan yang lebih baik, peningkatan nutrisi, bantuan untuk penuaan, keamanan keuangan yang lebih besar, mengurangi kerusakan lingkungan. Hal ini diperdebatkan, masyarakat adalah kebutuhan yang tak terpenuhi terbesar dalam perekonomian global.

Kotler dan Amstrong (2008) menjelaskan tentang etika pemasaran dan tanggung jawab sosial yaitu pemasaran mendapatkan banyak kritik. Beberapa kritik ini dibenarkan; namun banyak juga yang tidak diterima. Kritik sosial menyatakan bahwa praktek pemasaran tertentu melukai konsumen individual, masyarakat secara keseluruhan, dan perusahaan lain. Dampak pemasaran pada konsumen individual adalah harga yang tinggi karena faktor biaya distribusi yang tinggi dan biaya iklan serta promosi yang tinggi, praktek yang menyesatkan tentang konsumen akan mendapatkan nilai lebih daripada yang biasa mereka dapatkan, pemaksaan penjualan oleh wiraniaga, produk yang tidak bermoral, berbahaya, atau tidak aman (kualitas atau fungsi produk yang buruk), pengusangan yang disengaja, dan pelayanan buruk kepada konsumen lemah.

Kritik sosial tersebut memberikan pemikiran akan adanya tindakan bisnis menuju pemasaran yang bertanggungjawab secara sosial (Kotler dan Amstrong, 2008) yaitu pemasaran yang mendukung kinerja jangka panjang, berorientasi konsumen, memiliki nilai pelanggan, inovatif, mengemban misi, berwawasan sosial, mengembangkan kebijakan etika pemasaran. Tindakan bisnis menuju pemasaran yang bertanggungjawab secara sosial ini sesuai dengan creating shared value $(\mathrm{CSV})$ perusahaan.

Berdasarkan latar belakang diatas, maka kegiatan creating shared value yang memberikan manfaat bagi pelanggan menjadi tema yang menarik untuk diteliti. Selain itu, pelanggan juga dapat merasakan secara langsung manfaat dari kegiatan tersebut. Jika hal ini terjadi, maka 
persepsi pelanggan penting untuk menjadi bahan pertimbangan perusahaan dalam mengambil keputusan atas produk dan pasar yang akan dituju, sehingga penelitian ini berjudul "Persepsi Pelanggan Terhadap Manfaat Kegiatan Creating Shared Value dan Keberlanjutan Usaha PT Unilever Indonesia Tbk".

Ruang lingkup penelitian ini hanya meneliti mengenai persepsi pelanggan terhadap manfaat kegiatan Creating Shared Value dan Keberlanjutan Usaha PT Unilever Indonesia Tbk. Responden yang dipilih adalah pelanggan yang merupakan konsumen individual yang menggunakan produk PT Unilever Indonesia Tbk dengan minimal pengeluaran untuk pembelian produk tersebut minimal sebesar Rp 200.0000 per bulannya. Penentuan pembelian produk sebesar Rp 200.000, karena produk Unilever merupakan produk kebutuhan hidup dan rumah tangga berupa produk food and drink, home care dan personal care, sehingga jika dilihat dari harga setiap produknya, maka pelanggan dapat membeli produk tersebut minimal Rp 200.000 untuk setiap bulannya.

Perumusan masalah penelitian ini adalah bagaimana persepsi pelanggan terhadap manfaat kegiatan Creating Shared Value dan Keberlanjutan Usaha PT Unilever Indonesia Tbk mengenai produk yang dibeli pelanggan.

Tujuan penelitian ini adalah untuk memperoleh bukti empiris persepsi pelanggan terhadap manfaat kegiatan Creating Shared Value dan Keberlanjutan Usaha PT. Unilever Indonesia Tbk mengenai produk yang dibeli.

Manfaat penelitian ini adalah (1) Menambah literatur mengenai Creating Shared Value; (2) Penelitian ini mendokumentasikan persepsi pelanggan individual terhadap manfaat kegiatan Creating Shared Value dan Keberlanjutan Usaha; (3) Hasil penelitian ini diharapkan dapat membantu stakeholder secara keseluruhan dan pelanggan pada khususnya dalam mengambil keputusan membeli produk Unilever; (4) Hasil penelitian diharapkan dapat meningkatkan reputasi perusahaan atas manfaat kegiatan Creating Shared Value dan dampaknya terhadap keberlanjutan usaha PT Unilever Indonesia Tbk.

\section{Tinjauan Literatur}

\section{Stakeholder Theory}

Dalam teori stakeholder bahwa laba akuntansi merupakan ukuran return bagi pemegang saham (shareholder), sementara value added adalah ukuran yang lebih akurat yang diciptakan oleh stakehoders dan kemudian didistribusikan kepada stakeholders yang sama (Meek and Gray, 1988). Value added yang dianggap memiliki akurasi lebih tinggi dihubungkan dengan manfaat yang dianggap sebagai ukuran bagi stakeholder. Pelanggan yang merupakan salah satu bagian dari stakeholder menerima nilai manfaat dari kegiatan Creating Shared Value dan berdampak positif pada perusahaan karena memberikan strategi dan keunggulan yang kompetitif, sehingga manfaat Creating Shared Value diperlukan sebagai timbal balik dari perusahaan peduli terhadap stakeholder dan masyarakat lingkungan sekitar perusahaan, hal inilah yang dapat menjelaskan kekuatan teori stakeholder dalam kaitannya dengan kegiatan Creating Shared Value (Porter and Kramer, 2011).

\section{Persepsi Pelanggan}

Persepsi didefinisikan sebagai proses yang dilalui orang lain dalam memilih, mengorganisasikan, dan menginterpretasikan informasi guna membentuk gambaran yang berarti mengenai dunia (Remiasa dan Lukman, 2007). Proses memilih, mengorganisasikan dan menginterpretasikan informasi tersebut membuat seseorang akan memberikan makna dalam bentuk pendapat atas kegiatan tertentu. Hal ini dapat diartikan persepsi pelanggan adalah pernyataan pendapat pelanggan tentang kegiatan yang dilakukan. 


\section{Creating Shared Value}

Creating Shared Value (CSV) merupakan konsep strategi bisnis yang menetapkan perlunya memikirkan masalah dan kebutuhan sosial pada perancangan strategi perusahaan, sehingga keberhasilan perusahaan yang lebih baik dihubungkan dengan perbaikan sosial, membuka banyak cara untuk melayani kebutuhan baru, mendapatkan efisiensi, menciptakan diferensiasi produk, dan memperluas pasar. CSV merupakan pengembangan dari konsep tanggung jawab sosial perusahaan (Corporate Social Responsibility). Ada tiga cara yang berbeda untuk melakukan kegiatan Creating Shared Value yaitu: meredefinisi produk dan pasar, redefinisi produktivitas dalam rantai nilai, dan mengembangkan klaster industri pendukung di lokasi perusahaan (Porter and Kramer, 2011).

Manfaat kegiatan Creating Shared Value bagi pelanggan adalah harga produk yang sesuai dengan manfaat yang didapatkan pelanggan, bernutrisi baik, produk aman dan bermutu tinggi, mudah dicari karena sistem logistik yang baik serta produk nyaman karena ramah lingkungan (Porter and Kramer, 2011).

Kegiatan Creating Shared Value juga berdampak positif terhadap perusahaan yaitu dengan adanya kegiatan ini, maka pelanggan akan loyal membeli produk unilever, produk semakin berkualitas tinggi, karyawan nyaman bekerja dan produktivitas perusahaan meningkat, memiliki keunggulan kompetitif dalam inovasi produk, serta memiliki reputasi yang baik di mata pelanggan dan masyarakat (Porter and Kramer, 2011).

\section{Keberlanjutan Usaha}

Berdasarkan analisis berkelanjutan representasi dari 'organisasi berkelanjutan' dalam laporan perusahaan, argumennya adalah bahwa organisasi telah mampu menolak perubahan substantif untuk bisnis seperti biasa melalui proses mengidentifikasi transformasi yang jelas (Tregidga, Milne dan Kearins 2014). Mewakili organisasi berkelanjutan dalam cara-cara tertentu tidak hanya membangun kemungkinan baru dalam hal hubungan antara organisasi dan lingkungan alam (Fineman, 1996; Livesey, 1999; Livesey, 2001), tetapi juga terlibat dalam perjuangan sosial dan politik yang lebih luas lebih mendefinisikan diterima organisasi/lingkungan/hubungan masyarakat - yang mungkin dianggap layak dihormati. Hal inilah yang mendukung perlunya keberlanjutan usaha melalui kegiatan Creating Shared Value yang memperhatikan lingkungan dan masyarakat sekitar.

\section{METODE PENELITIAN}

\section{Jenis Penelitian, Populasi dan Sampel}

Penelitian ini merupakan jenis penelitian deskriptif (Thio, Harianto dan Sosiawan, 2008). Sedangkan populasi dalam penelitian ini adalah pelanggan yang menggunakan produk Unilever yang berada di Jakarta Barat. Metode pengambilan sampel dilakukan dengan teknik Simple Random Sampling (pengambilan sampel acak sederhana). Dalam teknik ini, populasi yang akan dijadikan sampel merupakan pelanggan produk Unilever di Jakarta yang dipilih secara acak, yang mempunyai peluang yang sama untuk dipilih menjadi sampel. Adapun sampel penelitian ini adalah 30 sampel.

\section{Jenis dan Sumber Data}

Jenis data yang digunakan dalam penelitian ini adalah data primer, yaitu data dikumpulkan khusus dan berhubungan langsung dengan permasalahan yang diteliti. Teknik pengumpulan data dalam penelitian ini dilakukan dengan kuesioner yang disebarkan kepada orang-orang yang merupakan pelanggan produk Unilever. Kuesioner tersebut menggunakan skala likert atau lima angka (Sekaran, 2003) yaitu skala yang didesain untuk menelaah seberapa kuat subjek setuju atau tidak setuju dengan pernyataan pada skala 5 titik dimulai dari angka 1 untuk alternatif 


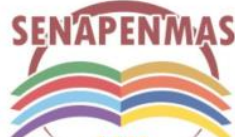

2021

jawaban sangat tidak setuju, angka 2 untuk alternatif jawaban tidak setuju, angka 3 untuk alternatif jawaban netral, angka 4 untuk alternatif jawaban setuju dan angka 5 untuk alternatif jawaban sangat setuju.

\section{Definisi Operasional Variabel}

Variabel-variabel yang digunakan dalam penelitian ini terdiri dari:

a. Persepsi pelanggan terhadap manfaat kegiatan Creating Shared Value bagi pelanggan merupakan suatu proses dalam memilih, mengorganisasikan dan menginterpretasikan manfaat kegiatan Creating Shared Value bagi pelanggan. Variabel ini diukur berdasarkan pada indikator persepsi tentang manfaat kegiatan Creating Shared Value bagi pelanggan (Porter and Kramer, 2011), yaitu:

1) Harga produk sesuai manfaat yang didapatkan.

2) Produk bernutrisi baik.

3) Produk aman digunakan dan bermutu tinggi.

4) Produk mudah dicari karena sistem logistik yang baik.

5) Produk nyaman digunakan karena perusahaan ikut pelestarian lingkungan.

b. Persepsi pelanggan terhadap manfaat kegiatan Creating Shared Value berdampak positif terhadap perusahaan adalah proses memilih, mengorganisasikan dan menginterpretasikan manfaat kegiatan Creating Shared Value yang berdampak positif terhadap perusahaan. Variabel ini diukur berdasarkan pada indikator persepsi tentang manfaat kegiatan Creating Shared Value berdampak positif terhadap perusahaan (Porter and Kramer, 2011), yaitu:

1) Pelanggan loyal membeli produk.

2) Produk berkualitas tinggi.

3) Karyawan yang nyaman bekerja dan produktif.

4) Keunggulan kompetitif dalam inovasi produk.

5) Reputasi perusahaan yang baik.

c. Persepsi pelanggan terhadap keberlanjutan usaha PT Unilever Indonesia Tbk merupakan suatu proses dalam memilih, mengorganisasikan dan menginterpretasikan manfaat kegiatan Creating Shared Value yang berdampak pada keberlanjutan usaha PT Unilever Indonesia Tbk. Pengukuran variabel didasarkan pada indikator persepsi pelanggan terhadap keberlanjutan usaha (Tregidga, Milne dan Kearins 2014) PT Unilever Indonesia Tbk, yaitu: pelanggan akan secara terus menerus memilih dan membeli produk Unilever karena PT Unilever Indonesia Tbk melakukan kegiatan Creating Shared Value yang berdampak pada keberlanjutan usaha Perusahaan.

Variabel ini menggunakan kuesioner open question, sehingga setiap pelanggan atau responden akan memberi pendapatnya masing-masing.

\section{Teknik Analisis Data}

Data yang sudah terkumpul akan diuji terlebih dahulu sebelum melakukan proses analisis, yaitu:

a. Pengujian Instrumen Pengumpulan Data

Pengujian instrumen pengumpulan data merupakan langkah awal yang harus digunakan untuk memastikan kuesioner yang disebarkan layak digunakan untuk memperoleh data yang diinginkan dari responden. Uji instrumen pengumpulan data yang digunakan dalam penelitian ini adalah:

1) Uji Validitas

Uji validitas digunakan untuk mengukur sah atau valid tidaknya suatu kuesioner. Suatu kuesioner dikatakan valid jika pertanyaan pada kuesioner mampu untuk mengungkapkan sesuatu yang akan diukur oleh kuesioner tersebut. Cara yang digunakan untuk mengukur validitas dalam penelitian ini adalah melakukan korelasi antar skor butir pertanyaan atau 


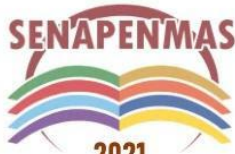

2021

pernyataan dengan total skor konstruk atau variabel. Uji signifikansi dilakukan dengan membandingkan nilai $\mathrm{r}$ hitung dengan $r$ table untuk degree of freedom $(\mathrm{df})=\mathrm{n}-2$, dalam hal ini n adalah jumlah sampel (Ghozali, 2012: 52-53).

2) Uji Reliabilitas

Reliabilitas sebenarnya adalah alat untuk mengukur suatu kuesioner yang merupakan indikator dari variabel atau konstruk. Suatu kuesioner dikatakan reliable atau handal jika jawaban seseorang terhadap pernyataan adalah konsisten atau stabil dari waktu ke waktu. Pengukuran reliabilitas dalam penelitian ini dilakukan dengan cara one shot atau pengukuran sekali saja. Disini pengukurannya hanya sekali dan kemudian hasilnya dibandingkan dengan pertanyaan lain atau mengukur korelasi antar jawaban pernyataan. SPSS memberikan fasilitas untuk mengukur reliabilitas dengan uji statistik Cronbach Alpha $(\alpha)$. Suatu konstruk atau variabel dikatakan reliabel jika memberikan nilai Cronbach Alpha > 0.70 (Ghozali, 2012:47-48).

b. Statistik Deskriptif

Statistik deskriptif memberikan gambaran atau deskripsi suatu data yang dilihat dari nilai rata-rata (mean), standar deviasi, varian, maksimum, minimum, sum, range, kurtosis dan skewness (Ghozali, 2012:19). Statistik deskriptif yang digunakan adalah nilai minimum, nilai maximum, mean dan standar deviasi.

c. Analisis Top Two Boxes Bottom Two Boxes

Analisis ini adalah analisis yang menerapkan penggabungan presentase jawaban responden dalam skala likert. Analisis Top Two Boxes Bottom Two Boxes ini dapat digunakan untuk mengetahui perbandingan antara jumlah bottom option (skor 1,2) yaitu skala sangat tidak setuju dan tidak setuju dengan top option (skor 4, 5) yaitu skala setuju dan sangat setuju. Selanjutnya Top Two Boxes akan disingkat (TTB), sedangkan Bottom Two Boxes akan disingkat (BTB) (Thio, Harianto dan Susawan, 2008).

\section{HASIL DAN PEMBAHASAN Demografis Responden}

Demografi responden yang menyajikan informasi berupa data responden yang meliputi jenis pekerjaan, jenis kelamin, tingkat pendidikan dan tingkat pengeluaran. Jenis pekerjaan dalam penelitian ini dikelompokkan menjadi empat yaitu mahasiswa, karyawan, wiraswasta dan lainnya. Dilihat dari jenis pekerjaan sebagian besar responden yang mengisi kuesioner ini adalah responden yang bekerja sebagai karyawan yaitu sebesar $84 \%$ dari jumlah keseluruhan responden. Responden yang bekerja sebagai mahasiswa yaitu sebesar 3\%, responden yang bekerja sebagai wiraswasta yaitu sebesar $10 \%$, dan yang lainnya yaitu sebesar 3\%. Dilihat dari jenis kelamin, responden yang mengisi kuesioner sebagai besar adalah wanita yaitu sebesar $60 \%$ dari jumlah keseluruhan responden dan sisanya $40 \%$ adalah responden yang berjenis kelamin pria.

Usia dalam penelitian ini dikelompokkan menjadi empat yaitu antara 20 - 30 tahun, antara 3140 tahun, antara 41 - 50 tahun, dan di atas 50 tahun. Dilihat dari faktor usia, sebagaian besar responden yang mengisi kuesioner ini adalah berusia 20 - 30 tahun yaitu sebesar $50 \%$ dari jumlah keseluruhan responden. Responden yang berusia 31 - 40 tahun yaitu sebesar 27\%, responden yang berusia di atas 50 tahun yaitu sebesar 17\% dan responden yang berusia 41 - 50 tahun yaitu sebesar $6 \%$.

Tingkat pendidikan dalam penelitian ini dikelompokkan menjadi lima yaitu SMA, D3, S1, S2 dan S3. Dilihat dari faktor tingkat pendidikan, jenjang terakhir sebagai besar responden yang mengisi kuesioner ini adalah S1 yaitu sebesar 60\% dari jumlah keseluruhan responden. Responden yang berpendidikan SMA yaitu sebesar 17\%, responden yang berpendidikan S2 juga sebesar $17 \%$, responden yang berpendidikan D3 yaitu sebesar $6 \%$, dan responden yang berpendidikan $\mathrm{S} 3$ adalah 0\%. 


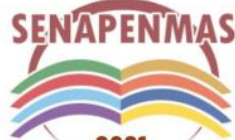

2021
Seminar Nasional Hasil Penelitian dan Pengabdian Kepada Masyarakat 2021 Pengembangan Ekonomi Bangsa Melalui Inovasi Digital Hasil Penelitian dan Pengabdian Kepada Masyarakat Jakarta, 21 Oktober 2021

Tingkat pengeluaran per bulan untuk membeli produk Unilever dalam penelitian ini dikelompokkan menjadi empat yaitu pengeluaran di bawah $\mathrm{Rp} 200.000$, lebih besar sama dengan Rp 200.000 sampai Rp 400.000, lebih besar dari Rp 400.000 sampai Rp 600.000, dan di atas Rp 600.000. Dilihat dari tingkat pengeluaran, sebagian besar responden mengeluarkan lebih besar sama dengan Rp 200.000 sampai Rp 400.000 per bulan yaitu sebesar $77 \%$ dari jumlah keseluruhan responden. Responden yang tingkat pengeluaran lebih besar dari Rp 400.000 sampai Rp 600.000 per bulan yaitu sebesar $13 \%$, responden yang tingkat pengeluaran di atas Rp 600.000 per bulan yaitu sebesar10\%, dan responden yang tingkat pengeluaran di bawah Rp 200.000 per bulan yaitu sebesar $0 \%$.

\section{Pengujian Kualitas Data}

Hasil pengujian validitas yaitu nilai $r$ tabel pada signifikansi 0,05 dengan uji 2 sisi dan jumlah data $(\mathrm{n})=30$ atau $\mathrm{df}=28$, maka didapat $\mathrm{r}$ tabel sebesar 0,361. Berdasarkan hasil pengujian validitas, nilai corrected item - total correlation untuk semua pernyataan variabel persepsi pelanggan terhadap manfaat kegiatan Creating Shared Value bagi pelanggan adalah antara 0,472 sampai dengan 0,648. Hasil nilai corrected item - total correlation ( $\mathrm{r}$ hitung) lebih besar dari 0,361 ( $\mathrm{r}$ tabel) maka dapat disimpulkan bahwa semua item pernyataan variabel persepsi pelanggan terhadap manfaat kegiatan Creating Shared Value bagi pelanggan dinyatakan valid.

Berdasarkan hasil pengujian validitas, nilai corrected item - total correlation untuk semua pernyataan variabel persepsi pelanggan terhadap manfaat kegiatan Creating Shared Value berdampak positif bagi perusahaan adalah antara 0,421 sampai dengan 0,747. Karena nilai corrected item - total correlation ( $\mathrm{r}$ hitung) lebih besar dari 0,361 ( $\mathrm{r}$ tabel) maka dapat disimpulkan bahwa semua item pernyataan variabel persepsi pelanggan terhadap manfaat kegiatan Creating Shared Value berdampak positif bagi perusahaan dinyatakan valid.

Hasil pengolahan data untuk uji reliabilitas menunjukkan nilai Cronbach's Alpha untuk variabel persepsi pelanggan terhadap manfaat kegiatan Creating Shared Value bagi pelanggan adalah 0,809. Hasil nilai Cronbach's Alpha sebesar 0,809 lebih besar dari 0,6 maka dapat disimpulkan bahwa item pernyataan dalam kuesioner mengenai persepsi pelanggan terhadap manfaat kegiatan Creating Shared Value bagi pelanggan yang digunakan dalam penelitian ini adalah dapat diandalkan atau reliabel.

Berdasarkan hasil pengolahan data untuk uji reliabilitas diketahui bahwa nilai Cronbach's Alpha untuk variabel persepsi pelanggan terhadap manfaat kegiatan Creating Shared Value berdampak positif bagi perusahaan adalah 0,821. Karena nilai Cronbach's Alpha sebesar 0,821 lebih besar dari 0,6 maka dapat disimpulkan bahwa item pernyataan dalam kuesioner mengenai persepsi pelanggan terhadap manfaat kegiatan Creating Shared Value berdampak positif bagi perusahaan yang digunakan dalam penelitian ini adalah dapat diandalkan atau reliabel.

\section{Statistik Deskriptif}

Variabel persepsi pelanggan terhadap manfaat kegiatan Creating Shared Value bagi pelanggan menunjukkan bahwa nilai minimum yang terdapat pada tabel adalah 3 yaitu jawaban responden atas pernyataan tersebut adalah netral, dan nilai maximumnya adalah 5 yaitu sangat setuju. Nilai mean pada tabel adalah antara 3,93 sampai 4,47 sehingga dapat dikatakan bahwa jawaban dari responden cenderung netral dan setuju. Standar deviasi merupakan besarnya penyimpangan varian data terhadap nilai rata-ratanya.

Variabel persepsi pelanggan terhadap manfaat kegiatan Creating Shared Value berdampak positif bagi perusahaan menunjukkan bahwa nilai minimum yang terdapat pada tabel adalah 2 yaitu jawaban responden atas pernyataan tersebut adalah tidak setuju, dan nilai maximumnya adalah 5 yaitu sangat setuju. Nilai mean pada tabel adalah antara 3,77 sampai 4,07 sehingga 
dapat dikatakan bahwa jawaban dari responden cenderung netral dan setuju. Standar deviasi merupakan besarnya penyimpangan varian data terhadap nilai rata-ratanya.

\section{Analisis Top Two Boxes Bottom Two Boxes}

Analisis Top Two Boxes Bottom Two Boxes bermanfaat untuk mengetahui persepsi responden yaitu pelanggan terhadap manfaat kegiatan Creating Shared Value dilihat dari jawaban teratas, yaitu responden yang menjawab sangat setuju dan setuju untuk tiap indikator. Untuk analisis Top Two Boxes (TTB) diambil dua indikator dengan nilai tertinggi, sedangkan untuk Bottom Two Boxes (BTB) diambil dari dua indikator dengan nilai terendah.

\section{Tabel 1}

Analisis Top Two Boxes dan Bottom Two Boxes Persepsi Pelanggan Terhadap Manfaat Kegiatan Creating Shared Value Bagi Pelanggan Sumber: Diolah Peneliti

\begin{tabular}{llccc}
\hline No & \multicolumn{1}{c}{ Indikator Persepsi } & $\begin{array}{c}\text { TTB } \\
(\boldsymbol{\%})\end{array}$ & Netral & $\begin{array}{c}\text { BTB } \\
(\boldsymbol{\%})\end{array}$ \\
\hline 1 & $\begin{array}{l}\text { Produk mudah dicari karena sistem logistik yang baik } \\
(\mathrm{Q} 4)\end{array}$ & 96,67 & 3,33 & 0 \\
\hline 2 & Harga produk sesuai manfaat yang didapatkan (Q1) & 83,33 & 16,67 & 0 \\
\hline 3 & Produk bernutrisi baik (Q2) & 83,33 & 16,67 & 0 \\
\hline 4 & Produk aman digunakan dan bermutu tinggi (Q3) & 83,33 & 16,67 & 0 \\
\hline 5 & $\begin{array}{l}\text { Produk nyaman digunakan karena perusahaan ikut } \\
\text { pelestarian lingkungan (Q5) }\end{array}$ & 76,67 & 23,33 & 0 \\
\hline
\end{tabular}

Berdasarkan Tabel 1 analisis Top Two Boxes data diketahui bahwa 96,67\% responden setuju terhadap pernyataan indikator persepsi yang menyatakan bahwa produk Unilever mudah dicari karena sistem logistik yang baik (Q4), dibandingkan produk yang lain. Selain itu berdasarkan analisa Bottom Two Boxes responden menyatakan tidak ada yang tidak setuju (0\%) terhadap pernyataan indikator persepsi. Hal ini dapat disimpulkan bahwa seluruh pernyataan indikator berhubungan dengan persepsi pelanggan terhadap manfaat kegiatan Creating Shared Value bagi pelanggan.

Tabel 2 analisis Top Two Boxes data diketahui bahwa responden setuju 83,34\% terhadap pernyataan indikator persepsi yang menyatakan bahwa produk Unilever memiliki keunggulan kompetitif dalam inovasi produk (Q4), dibandingkan produk yang lain. Selain itu berdasarkan analisa Bottom Two Boxes 3,33\% responden menyatakan yang tidak setuju terhadap pernyataan indikator persepsi. Hal ini dapat disimpulkan bahwa seluruh pernyataan indikator berhubungan dengan persepsi pelanggan terhadap manfaat kegiatan Creating Shared Value berdampak positif bagi perusahaan.

Tabel 2

Analisis Top Two Boxes dan Bottom Two Boxes

Persepsi Pelanggan Terhadap Manfaat Kegiatan Creating Shared Value Berdampak Positif Bagi Perusahaan

Sumber: Diolah Peneliti

\begin{tabular}{llccc}
\hline No & \multicolumn{1}{c}{ Indikator Persepsi } & TTB & Netral & $\begin{array}{c}\text { BTB } \\
(\boldsymbol{\%})\end{array}$ \\
\hline 1 & Keunggulan kompetitif dalam inovasi produk (Q4) & 83,34 & 13,33 & 3,33 \\
\hline 2 & Reputasi perusahaan yang baik (Q5) & 80 & 16,67 & 3,33 \\
\hline 3 & Pelanggan loyal membeli produk (Q1) & 76,67 & 23,33 & 0 \\
\hline
\end{tabular}




\begin{tabular}{clccc}
\hline 4 & Produk berkualitas tinggi (Q2) & 73,34 & 23,33 & 3,33 \\
\hline 5 & Karyawan yang nyaman bekerja dan produktif $(\mathrm{Q} 3)$ & 60 & 40 & 0 \\
\hline
\end{tabular}

\section{Persepsi Pelanggan Terhadap Keberlanjutan Usaha PT Unilever Indonesia Tbk}

Berdasarkan hasil jawaban pertanyaan kepada responden bahwa responden sebagai pelanggan setuju akan terus menerus memilih dan membeli produk Unilever karena PT Unilever Indonesia Tbk melakukan kegiatan Creating Shared Value yang berdampak pada keberlanjutan usaha perusahaan karena:

1. Terbukti kualitas produknya

2. Sudah merupakan kebutuhan hidup

3. Harga yang terjangkau

4. Mutu produk yang tinggi

5. Kesinambungan produk yang baik

6. Produk sesuai selera pelanggan

7. Produk cocok dengan keluarga

8. Membantu masyarakat sekitar perusahaan

9. Iklan yang menarik

10. Produk mudah dicari

11. Produk ramah lingkungan

12. Produk sudah menjadi kebiasaan

\section{KESIMPULAN DAN SARAN}

Kesimpulan dari penelitian ini adalah bahwa pelanggan memiliki respon yang baik terhadap manfaat kegiatan Creating Shared Value bagi pelanggan sendiri maupun yang berdampak positif bagi perusahaan karena akan berguna bagi keberlanjutan usaha PT Unilever Indonesia Tbk. Hasil dari persepsi pelanggan terhadap manfaat kegiatan Creating Shared Value lebih tinggi persentase setujunya terletak pada produk yang mudah dicari karena memiliki system logistik yang baik dan keunggulan kompetitif atas inovasi produk Unilever.

Keterbatasan penelitian ini adalah sampel yang diambil dari salah satu kota adalah kota Jakarta yaitu Jakarta Barat, sehingga hasilnya tidak dapat digunakan sebagai generalisasi untuk semua pelanggan dari produk Unilever di Indonesia.

Penelitian selanjutnya disarankan menggunakan analisa regresi berganda dalam melihat pengaruh loyalitas pelanggan membeli produk Unilever berdasarkan manfaat dari kegiatan Creating Shared Value yang akan berdampak pada Keberlanjutan Usaha PT Unilever Indonesia Tbk.

Ucapan Terima Kasih (Acknowledgement)

Terima kasih kepada Gabriela, selaku asisten peneliti yang telah membantu dalam penyebaran kuesioner dan penginputan data.

\section{REFERENSI}

Fineman, S. (1996). Emotional Subtexts in Corporate Greening. Organization Studies, 17(3), 478-500.

Ghozali, I. (2012). Aplikasi Analisis Multivariate dengan Program IBM SPSS 20. Edisi 5. Semarang: Badan Penerbit Universitas Diponegoro.

Gunawan, J. (2015). Buku Panduan Laporan Berkelanjutan: Prinsip Menentukan Isi dan Kualitas. Jakarta: Mitra Wacana Media.

Kotler, P. \& Gary, A. (2008). Principles of Marketing. Twelfth Edition. Prentice Hall. 
Livesey, S. (1999). McDonald's and the Environmental Defence Fund: A Case Study of a Green Alliance. The Journal of Business Communication, 36(1), 5-39.

Livesey, S. (2001). Eco-identity as Discursive Struggle: Royal Dutch/Shell, Brent Spar, and Nigeria. The Journal of Business Communication, 38(1), 58-91.

Meek, G. K. \& Gray, S. J. (1988). The Value Added Statement: An Innovation for The US Companies. Accounting Horizons, 12 (2), 73-81.

Porter, M. \& Mark, R. K. (2011). Creating Shared Value: How to Reinvent Capitalism-and Unleash a Wave of Innovation and Growth. Harvard Business Review, Jan/Feb, 63-70.

Remiasa, M. \& Lukman, Y. (2007). Analisis Persepsi Pelanggan Terhadap Kualitas Layanan Coffee Shop Asing dan Coffee Shop Lokal. Jurnal Manajemen Perhotelan, 3(2), 70-79.

Sekaran, U. (2003). Research Methods for Business. Fourth Edition. John Wiley \& Sons, Inc.

Spitzeck, H \& Sonia, C. (2012). Creating Shared Value as a Differentiation Strategy - The Example of BASF in Brazil. Corporate Governance, 12(4), 499-513.

Thio, S. Harianto, N. Y. S. \& Sosiawan, R. F. (2008). Persepsi Konsumen Terhadap Makanan Organik di Surabaya. Jurnal Manajemen Perhotelan, 4(1), 18-27.

Tregidga, H. Milne, M. \& Kearins, K. (2014). (Re)presenting 'Sustainable Organizations'. Accounting, Organizations and Society, 39, 477-494. 